\title{
Paradoxes of Studentification: Social Mix versus Gentrification in a Disadvantaged Neighborhood in Amsterdam East
}

\author{
Kees Boersma ${ }^{1}$, Hannah Langen ${ }^{1, \S}$ and Peer Smets ${ }^{*}, 2$ \\ ${ }^{I}$ Department of Organizational Sciences, VU University Amsterdam, De Boelelaan 1081, 1081HV Amsterdam, The \\ Netherlands \\ ${ }^{2}$ Department of Sociology, VU University Amsterdam, De Boelelaan 1081, 1081 HV Amsterdam, The Netherlands
}

\begin{abstract}
Studio K, a relatively new quasi-public space in a gentrifying multi-ethnic neighborhood in Amsterdam East, is a prime example of the growing urban reinvestment within the area. The basic idea behind the by students managed Studio $\mathrm{K}$ is to create a cultural centre as an open place, including a cinema, restaurant, bar and club, where all visitors feel at home. It is the form and content that renders neighborhood relations relevant, not the physical proximity. Our paper involves a critical discussion of what can be understood as 'community commitment' and how the organizational identity of Studio K responded to the needs and expectations of the community in relation to the gentrification debate, and in particular studentification. Our analysis suggests that neighborhoods do not indicate the potential for social identification and shared community experience.
\end{abstract}

Keywords: Neighborhood development, studentification, gentrification, belonging.

\section{INTRODUCTION}

Recently there's been a growing interest in the reinvestment and revitalization of disadvantaged, inner-city neighborhoods. Government officials aren't the only ones to acknowledge the need for an improvement of living conditions in underprivileged districts, other stakeholders such as housing corporations, have become increasingly involved in the process of neighborhood change. The revitalization of urban neighborhoods 'involves the eradication of blight. It promotes increased economic activity in the form of business development and other private investments' [1]. Owner-occupied housing increasingly replaces social rental housing, which goes together with the assumption that a mix of different types of residents will lead to improvements in the neighborhood. The reduction of spatial inequalities can create access to facilities and services [2], in turn improving urban livability and enabling competition in a globalized knowledge-based economy [3]. However, scientific literature is critical of social mixing and shows that expected benefits are not always feasible and if so, not always beneficial to all residents [4-6], or could be seen as a way for the middle classes to reconquer the city $[7,8]$, and colonize urban areas [9].

Discussions on tenure and social mixing are increasingly linked with the phenomenon of gentrification, this becomes apparent once affluent citizens settle in a disadvantaged

\footnotetext{
*Address correspondence to this author at the Department of Sociology, VU University Amsterdam, De Boelelaan 1081, 1081HV Amsterdam, The Netherlands; Tel: 003120598 6769; Fax: 003120598 6765;

E-mail: p.g.s.m.smets@vu.nl

${ }^{\S}$ Independent Urban Scholar
}

neighborhood $[9,10]$. Although the focus of gentrification research differs greatly, the common focus is on the "classbased colonization of cheaper residential neighborhoods and (...) a reinvestment in the physical housing stock' [11]. Gentrification '[i]s fundamentally 'fit for purpose' in identifying, describing, and understanding the changing relationships between people and place, in a range of settings across the world.' [10]. Gentrification is the main driver behind the new glocal neighborhood, where elements of globalization and the local come together [11]. Although there are many ways of theorizing gentrification,

'[t]he interconnections between the negative and positive effects of gentrification are not well advanced. What are required are nuanced understandings of how different impacts of gentrification are interconnected and embedded within gentrified places and how these affect the quality of life and well-being of different social groups, both in the sense of material and non-material outcomes.' [12].

In order to look into these matters the gentrifiers should be identified, these include for example, professionals of both sexes, gay, 'conventional' households, plus those of a different ethnic or racial origin [11].

Students haven't received a lot of attention in the gentrification debate. When students chose to live in neighborhoods outside a university campus it becomes important to understand what the ensuing impact is on local communities. Research into this phenomenon demonstrates two extremes: either students mix with the local community or live apart together [12-16]. Processes of studentification as it is coined - go together with what Atkinson [11] calls 'the tracking of new settlement patterns of splinters of the 
middle-class'. To look into this process of gentrification one needs to understand that students strive for an independent lifestyle that helps them enter maturity. Students experiment and practice issues of autonomy and behavior [14], characterized by learning student rites and distancing themselves from the student infrastructure as the student is acculturated into the less 'typical' student activity in the city. [17]. Moreover, 'the changing complexion of studentification demonstrates that it isn't merely the transmutation of studentified areas; they are not seen to necessarily follow pre-ordained paths or trajectories' [12].

So far gentrification research emphasizes mainly the role of owner-occupiers and more specifically, students in rental housing. However, this study has a different focus. It will focus on the gentrification role of a cultural organization within which the employees predominantly come from outside the neighborhood. This article presents the case of Studio K, a cultural organization located in the east of Amsterdam, run by students. This is a prime example of the growing urban reinvestment in the Indische neighborhood; an ethnically mixed neighborhood in Amsterdam East. Figs. $(\mathbf{1}, \mathbf{2})$ depict the building in which Studio $\mathrm{K}$ is located and its entrance.

The role of students in the Indische neighborhood remains outspoken in Studio K, a large building located on one of the renovated neighborhood squares called

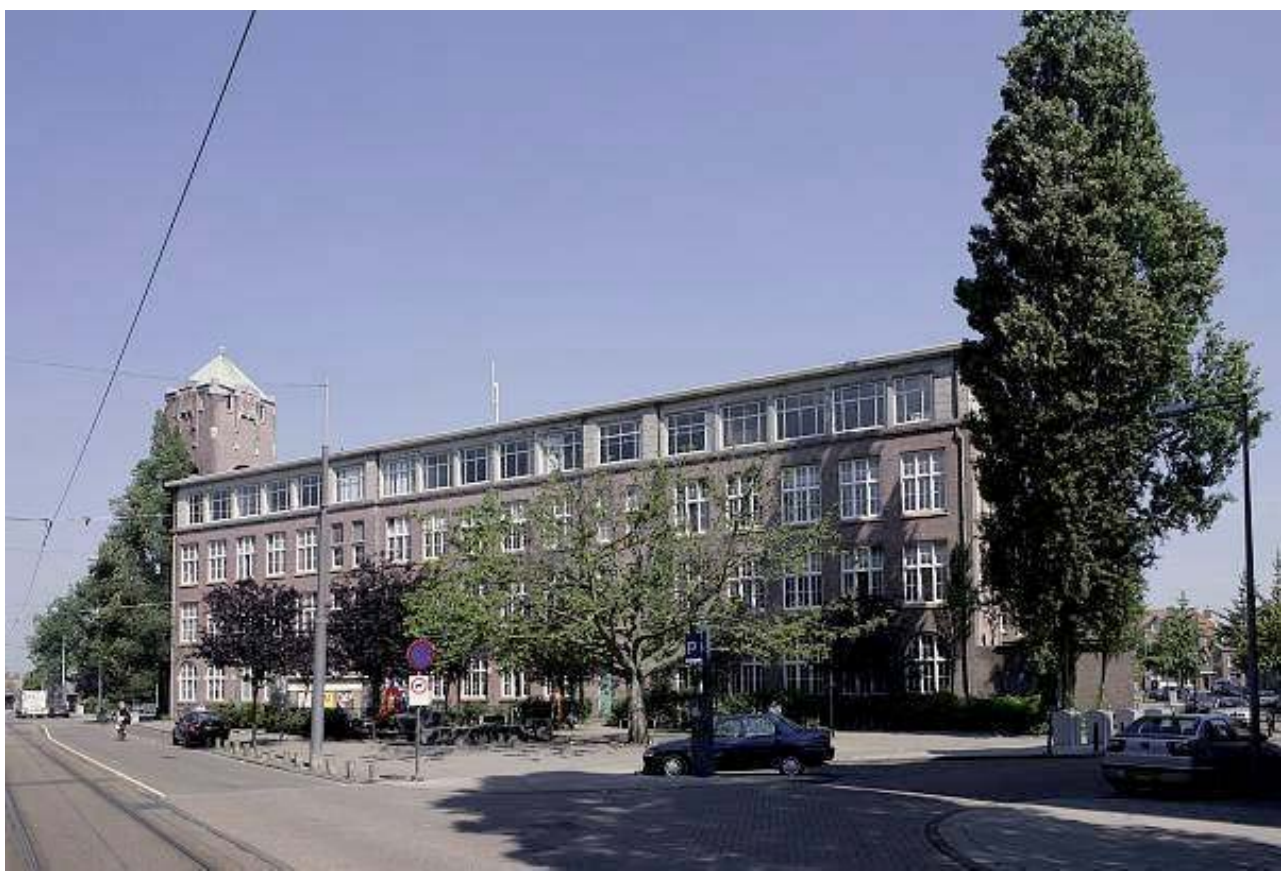

Fig. (1). The Timorplein Community Building (source: Studio K).

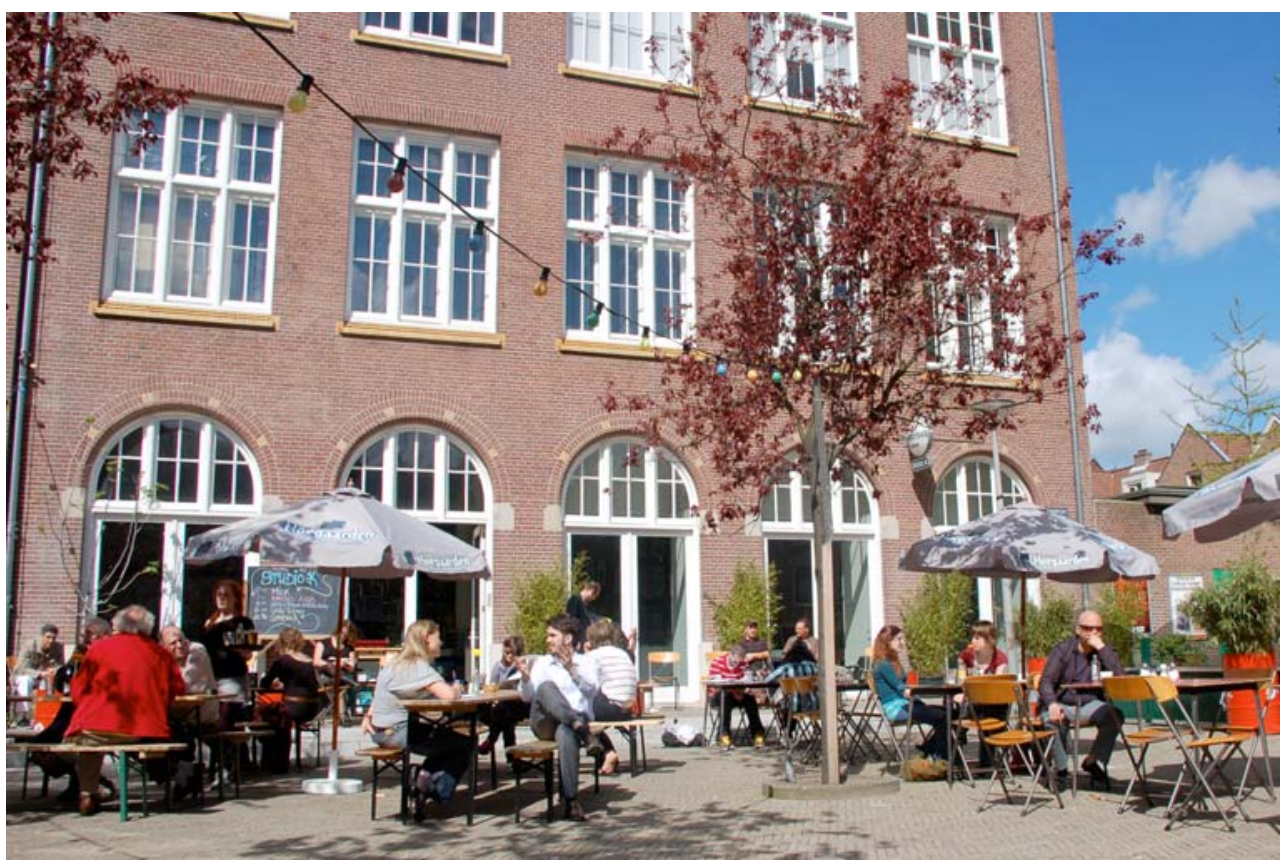

Fig. (2). Terrace of Studio K (source: Studio K). 
Timorplein. The basic idea behind Studio $\mathrm{K}$ was to create a cultural centre that serves different interests: a multicultural center that combines metropolitan ambitions with a 'living room' experience. The business plan of Studio K also states that it wishes to express the diverse influences echoed by the surrounding neighborhood.

This dual identity concept is outlined in the business plan: on the one hand Studio $\mathrm{K}$ is to be a multifunctional place which serves as cinema, restaurant, bar and club, thereby attracting not one specific group, but the urban dweller or the urban flâneur as such $[18,19]$. On the other hand, Studio $\mathrm{K}$ is pictured as an informal meeting place for an ethnically diverse neighborhood, as a place that through its activities actually represents the Indische neighborhood. Two-and-a-half years after the opening of Studio K, it remains questionable as to whether it functions as a place of leisure for the urban dweller and 'living room' for the surrounding neighborhood, or if those functions are still considered equally important. Plans concerning corporate policy have been written annually since the opening in September 2007, these show increasingly less ambition to serve the interests of the Indische neighborhood residents, whereas the aim to attract the culturally interested middle class have become more prominent.

Whether the impact of Studio K on the neighborhood can really be described as positive depends on whose point of view is being taken into consideration. Changes that occur in a neighborhood are essentially political in the sense that they serve some more than others, involving diverse, often conflicting ideologies. In this paper we investigate this organization by asking the question: What is the role of Studio $\mathrm{K}$ in the studentification of the Indische neighborhood in the east of Amsterdam, and how is that defined by its organizational structure?

In the rest of the paper, firstly we describe the specific urban context in which Studio $\mathrm{K}$ is situated. This is followed by a description of Studio K's organizational particularities. We then present a theoretical framework concerning the relationship of belonging, communities and identity in the context of urban development. After the methodology and methods section, we give the empirical findings with regard to Studio K as 'home' by paying attention to its identity and locality. We complete this article with a discussion and conclusion section.

\section{SETTING THE SCENE: A GENTRIFYING NEIGH- BORHOOD}

The Indische neighborhood is located in Amsterdam East (see Fig. 3). For the most part, the Indische neighborhood dates back to the early 20th century. Today the neighborhood's population is highly diversified. Statistics of 2010 show that $55 \%$ of residents are of non-western migrant background, most of which are of Moroccan, Turkish and Surinamese origin (www.os.amsterdam.nl).

The average income of the Indische neighborhood is relatively low when compared to the Amsterdam average. Following the common trend visible in the data, incomes have risen in the last few years however; it isn't clear as to whether that growth can be ascribed to a higher concentration of middle-class residents. Some conclusions can, however, be drawn by looking at the increase of owneroccupied housing. In 2005 around $11 \%$ of all housing was owner-occupied whereas in 2009, $16 \%$ of all housing was privately owned and occupied. Housing corporations have shown great interest in the revitalization of this neighborhood, partly through the transformation of social

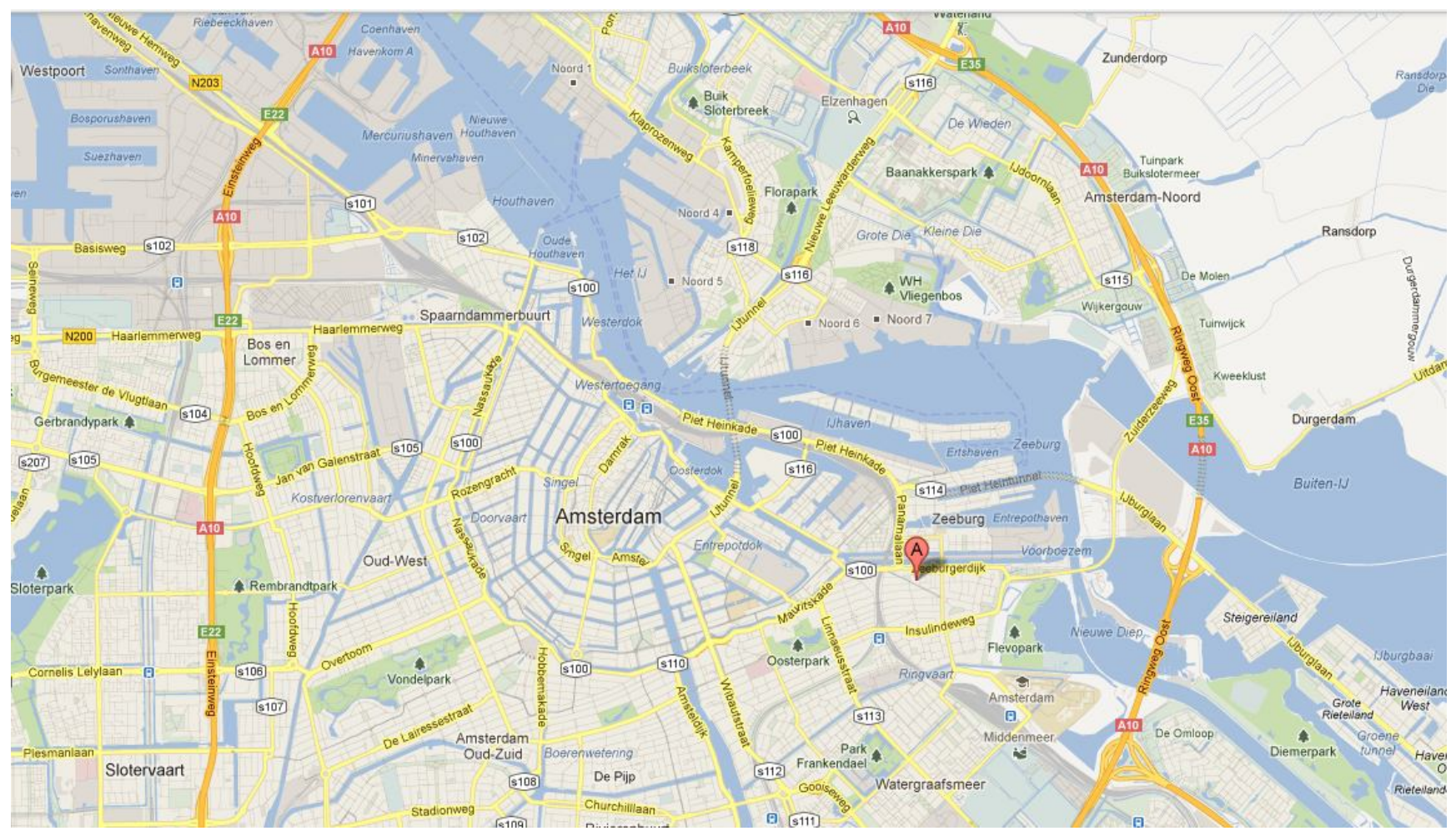

Fig. (3). Amsterdam and Studio K (See A at map) (Source: Google Maps). 
housing into owner-occupied housing. Moreover squares are being renovated and modern cafes along with fancy restaurants, opened. Thereby a new social class is attracted to new facilities such as Studio K, leading to an overall economic appreciation of the neighborhood.

\section{STUDIO K: THE ORGANIZATION}

Studio $\mathrm{K}$ is a part of the foundation Mutual Student Support (Stichting Onderlinge Studenten Steun, SOSS), established by a group of students in 1945 aiming to create employment for students so that it might be possible for them to finance their studies and gain working experience in the cultural and service sector. The foundation began with the cinema Kriterion and a baby-sitting agency, followed by a petrol station and a restaurant called Skek. Although the cinema Kriterion became an independent part of the foundation as a result of an incident in 1982 when students protested to prevent it's closing, all projects of the foundation still stick to the same organizational principles.

In line with the original principles, Studio $\mathrm{K}$ is a nonprofit organization where all earnings are reinvested in the activities of Studio $\mathrm{K}$ and SOSS. The organizational structure is non-hierarchical and all participants are volunteers, receiving no salary, but paid a monetary compensation for their work. The non-hierarchical structure and high involvement of all participants requires more meetings than one would usually expect in a work environment like Studio K. Everyone takes part in major decision making, the corporate policy is re-evaluated every twelve months and is approved by all members; otherwise it has to be rewritten. Yearly a new board is elected; they in turn complete an annual rewrite of the corporate-policy plans. Every plan concerning corporate policy has to be discussed and agreed on; this leaves little room for voices within the organization to go unheard. The organizational policy thereby has to be shouldered by the majority members; they form the organizational identity.

Recently, the critical financial situation Studio K found itself in put participating students under pressure to satisfy the interests of SOSS. Projects deemed unprofitable are often rejected and all activities have to reach break-even. Even though Studio $\mathrm{K}$ is a non-profit organization, the current focus is on profit making, or rather loss-control. Activities that involve the surrounding community might therefore be of less interest, with members weighing up benefit against risk.

\section{BELONGING, COMMUNITY AND IDENTITY}

One argument legitimizing the need to diversify housing stock in disadvantaged districts, such as the Indische neighborhood being that it attracts the middle classes, including students, thereby enhancing the chances of socioeconomically better-off neighborhoods, which become socially more cohesive. An improved environment is said to influence the capability of individuals to restore social capital [20], but this isn't always the case [6]. In other words, these interventions are expected to have a positive impact on the neighborhood and community, but the connection of the community and neighborhood is more complex. In large urban settings there remains uncertainty regarding the reciprocal influence of neighborhood and community $[6,21$, 22].

Location does not necessarily implicate community and shared public space does not indicate an interpretive scheme that is even, to some extent, shared: Location, however, does not intrinsically produce community: '(...) locally based identities intersect with other sources of meaning and social recognition, in a highly diversified pattern that allows for alternative interpretations' [23]. As a result, local environments per se do not induce a specific pattern of behavior, or, for that matter, 'a distinctive identity' [24]. In other words, to reside in a specific neighborhood does not necessarily implicate that the neighborhood forms the scope of day-to-day activities. Practices of everyday encounters, are however the entity that defines a community. Neighborhoods do not as such indicate the potential for social identification and community experience. It is the form and content that renders neighborhood relations relevant and not physical proximity. People experience, and thus perceive interactions differently, which is the process of sense making [25] that defines the substance of community.

An additional issue of importance for feeling at home is to recognize it as multi-layered and emotionally linked to the physical and social characteristics of a specific place. In order to get a hold on different views on belonging, Duyvendak [26] distinguishes universalist en particular views on home. The universalists [23] stress that the importance of place and space attachment is almost absent due to globalization, while particularists $[27,28]$ emphasize that place is important for feeling at home in a turbulent world. Savage et al. [27] speak of elective belongers, which come today and stay tomorrow in a neighborhood, while Watt [28] introduces the concept of selective belonging, implying that people feel at home only in an exclusive spatially and socially determined zone in a neighborhood, where they come today and are gone tomorrow. Particular places, in combination with a positive valued mobility, lead to strong attachments to specific place. Such place can be a home for mobile people, where taste and smell enable a sense of belonging. Apart from mobile people, mobile goods such as ethnic foods are brought in for consumption.

In relation to quasi-public space - such as restaurants, cafés and cultural centers - it is important to look at the organizational structure and how this influences daily encounters in such a place, therefore performing a specific identity that reconsiders the link of multiple identities with neighborhood residents [29]. What values are referred to, and which practices to apply depends entirely on the situation. Identity traits are not arranged in a hierarchy, their formation shifts when required. As organizational action is multi-directional, so is identity [30-32]. In accomplishing multiple identities, organizations show an inclination to retain some ambiguity in their identities [29]. Moreover, one has to realize that the external image of an organization does not necessarily reflect the identity organizational members assume [33]. Organizational identity has a tendency towards adaptive instability [29]. Finally, identification only influences thought, feeling and action when the associated identity is salient, that is, situation-relevant and subjectively important [34]. This could be explained by the organizational identity and narratives spread regarding 
image, attracting those people who feel an affinity for it. In other words, the identity of Studio $\mathrm{K}$ and the social identity of members and visitors match [35].

Studio $\mathrm{K}$ puts emphasis on its ability to stimulate community building. If community is assessed with regard to personal relationships, then the importance of Studio K for the surrounding neighborhood can only accurately be described in terms of the interpretive scheme that underlies the interactions between the organizational members and residents. However, neighborhood revitalization does not necessarily lead to an improvement of the bonding capacity of the residents. In their rich empirical study, Putnam and Feldstein illustrate different initiatives that aim to encourage community building. They rely on social capital theory to describe their findings; mainly they distinguish between bonding and bridging capital. Social capital that is accumulated in networks linking people that share similar backgrounds and interests, are referred to as bonding. Bridging social capital on the other hand, concerns networks between different types of people [36, 37]. These networks are characterized as outward looking, while features of networks that produce bonding social capital are determined as inward looking.

Theoretically speaking, Studio K provides an opportunity for residents to mix with other people and revitalize their relationships with each other. Yet, as we will see in the empirical part of this paper, the focus of activities has shifted away from neighborhood bridging to more inward looking and bonding activities, having consequences for the role of students in the local gentrification process.

\section{METHODOLOGY}

The research underlying this paper was ethnographic in nature - it included research in-situ. The fieldwork covered a period of one and a half years, starting in winter 2008. It brings theory to life and more importantly, adds new insights that hopefully enrich future research projects. In conducting this study, we were interested in determining the way in which Studio K's organizational members and stakeholders give meaning to its identity and policy [16]. In particular Weick's concept of sense making is consonant with our approach. For Weick [25], sense making is about '[s] uch things as placement of items into frameworks, comprehending, redressing surprise, constructing meaning, interacting in pursuit of mutual understanding and patterning.' (p.6) Following Weick, we see sense making as an ongoing process grounded in the identity construction of Studio $\mathrm{K}$ and rooted in the history and culture of the organization.

The data for this paper have been collected through fieldwork and participant observation. ${ }^{1}$ Following Alvesson [31] we think that: '[T]he use of a multitude of methods sometimes referred to as triangulation - is often to be preferred, not in order to zoom in on the truth through different methods, but in order to create a richer picture.' (p.172). A reflexive pragmatic view is taken to ground the interviews theoretically. Reflexivity for Alvesson [31], means seeing things and persons from different perspectives and angles. Next to a longitudinal participant observation or

${ }^{1}$ The second author of this paper worked for a couple of months at Studio K. as Alvesson would probably call it, observing participation, semi-structured interviews were conducted with outsiders and insiders. Ten interviews with members of Studio K were held in the period March-June 2010, former board members that wrote the first business plan were interviewed along with others that had worked at Studio K for an extended period, plus other short-term group members. These interviewees work in different parts of the organization; the cinema, club or restaurant. In addition, interviews were conducted with employees of the housing corporation Ymere, entrepreneurs situated in the same building as Studio $\mathrm{K}$, the neighborhood organization Timorplein Community, Art Community \& Culture (ACCU), along with people visiting a nearby community center.

All interviews were recorded and transcribed. Knowing the organization and its members personally and having lived in the neighborhood for some time enabled the researchers to contextualize the accounts given and not take what is said as an objective description of reality, as ethnographic research relies above all else, on an interpretive and not just a descriptive data analysis. Moreover, the research encompasses various sources of information such as e-mail conversations, meetings and internal documents concerning widespread organizational activities. Documents included all business plans written annually since the opening of Studio K, records of internal meetings as well as project plans designed for cultural programs and marketing strategies. During the fieldwork period all meetings were attended including those of specific project groups, the board, and the entire organization.

\section{STUDIO K IN-ACTION: ORGANIZATIONAL IDENTITY AND 'COMMUNITY COMMITMENT'}

The enormity of the building and its specific architecture make Studio K highly visible within the neighborhood. Its central location characterizes Studio K as a possible hub for the people living in the neighborhood. At first glance, Studio $\mathrm{K}$ displays an open and warm character. Huge windows over the entire ground floor let natural light in, creating a pleasant atmosphere. Moreover, there's a visibly drawn connection between Studio K and the neighborhood because you can see what is happening in the public space that surrounds Studio K. During summer, Studio K has a huge terrace on the Timorplein Square reinforcing interaction between guests and passers by. The interior of Studio K (see Figs. 3, 4) can be described as conservative with a comforting touch of chaos. On the ground floor in the middle of the space there is a big white bar open to both sides of a dividable restaurant. The two cinemas situated in a former theatre, are up the stairs. Even though the cinema ticket sales are in the foyer downstairs, there are still people unaware of the fact that Studio K has more to offer than just a restaurant. The open plan interior of Studio K makes it hard to overlook visitors and members alike. Most of the time there are a group of non-working members present studying, drinking coffee or just hanging out together. Guests therefore often mention that Studio K feels like it's a place owned by the people that work there, even though it's open to visitors.

Like other cultural venues in major cities, Studio $\mathrm{K}$ tries to present trend-setting events in a hip, arty surrounding. Most people working at Studio $\mathrm{K}$ belong to the higher 

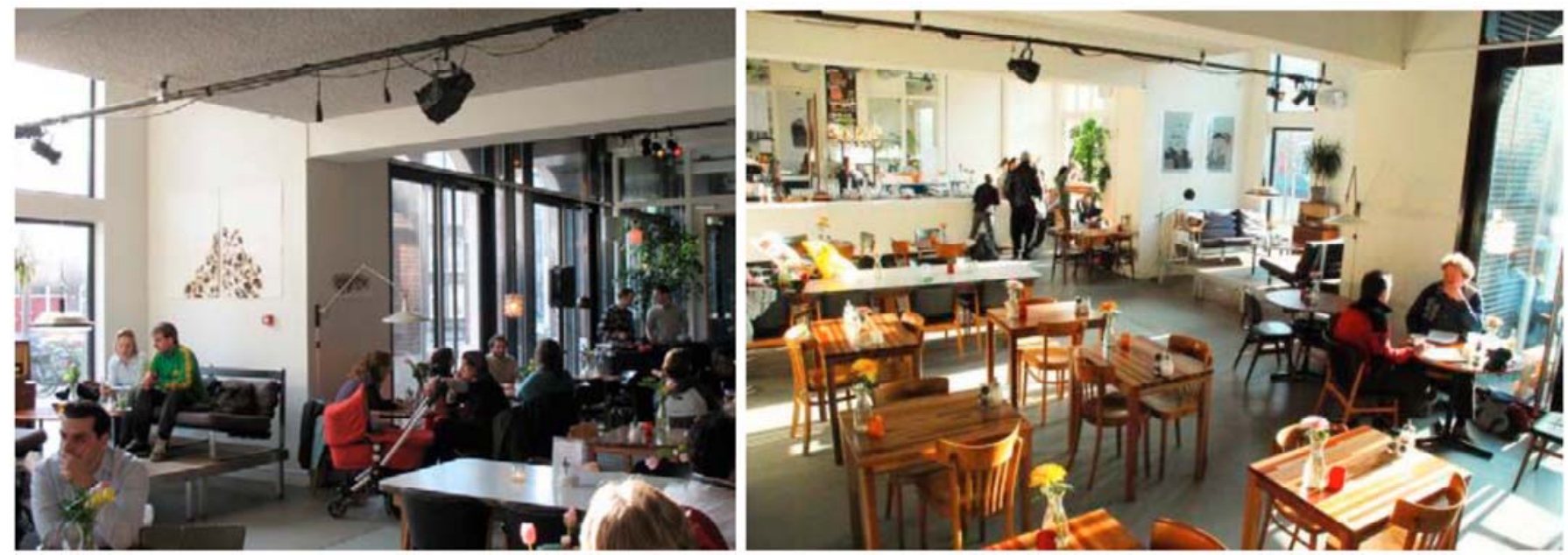

Fig. (4). Studio K the interior (source: freeamsterdam.blogspot.com and cineville.nl).

educated middle class and have grown up in an environment that cherishes art, education and music. They are the kind of people that search for upcoming, cultural events and experience them as open space.

Having a look at the common guest, one can say that most of the visitors including the older visitors, still appreciate Studio $\mathrm{K}$ for not being typical of the Indische neighborhood but for being a place that adds a touch of metropolitan lifestyle to the surrounding neighborhood. Even the menu and the films screened pay no reference to the specific character of the neighborhood. As one of the interviewees mentioned, one has a hard time finding halal dishes that meet the needs of the Muslim community, a group highly represented in the surrounding neighborhood, this also applies to Surinamese food. Films shown are mostly from European or American origin, encompassing $70 \%$ crossover, $20 \%$ art house and $10 \%$ niche films. Films that represent the ethnic diversity of the neighborhood have vanished; currently films shown clearly address mainly the 'white' Dutch middle class.

Next to the physical appearance of Studio K, its internal structure has been significant for the change of bearing it has undergone over time since it opened in September 2007. As a place that is entirely run by students, it misses the consistency of other commercial organizations. Students only stay temporarily and pertain to no clear direction in life as all doors seem to stand open in this period of their lives. In addition, their main activities are that of a student, they spend less time working, making them less professional. Most projects at Studio $\mathrm{K}$ succeed thanks to the improvisational skills of the students and not because they have a well-organized attitude.

The temporal nature of Studio K's staff is its biggest limitation. The average member of Studio K stays for around one year and then for a variety of reasons, leaves. Primarily, the workload gets too heavy or students decide to spend time abroad. Members are supposed to work sixteen to twenty hours a week, this only includes their major tasks within the organization. The high commitment of the members is the drive behind Studio K, guaranteeing the continued existence of the organization. It is however, also an aspect Studio K continuously struggles with. Leaving the organization after a few months, members take knowledge and skills with them and so far no one has figured out how to preserve that knowledge. In the first year of Studio K, the community formed one of the focal points of the organizational identity, bringing forward several activities.

Financial limitations also play a role: Studio $\mathrm{K}$ is unable to finance an old and new member working side by side. In the case of any community-building activities of Studio K, it can be concluded that frequently leaving member's lead to a loss of knowledge, not only where contact with the neighborhood is concerned, but also the focus on the ideal to strengthen community ties has disappeared. In total, the lack of continuity results in a process of reinventing the wheel again and again, as an influential member leaves or the board steps down to make room for a new one.

Enthusiasm for Studio K and its activities is one of the most important reasons students join the organization. Knowing the criteria applied during job interviews, it can be said that enthusiasm is a crucial motivation when applying for membership at Studio K. After three months, members are entitled to employ their say regarding the functioning of a newcomer when an anonymous evaluation is held. Only after having convinced the majority of the members, does a student become accepted as a member of the organization. The nature of the selection process displays a tendency to favor highly ambitious individuals. On the one hand this leads to a creative working atmosphere, encouraging members to constantly initiate new projects. On the other hand, individual ambitions often form the fundament of new projects.

During the last three years, only a few projects have managed to gain continuous enthusiasm, becoming a permanent part of the activities and repeatedly mentioned in the yearly business plans. The disappearance of the 'community building' activities of Studio K points to the departure of the founders of Studio K, who envisioned an organizational identity including the surrounding community. They also had their individual interests and ambitions but these were not transferred to others and gradually faded with their departure. 
It seems as if the community-building activities have diminished and need to be refocused on by the board or other members, taking care that the long-departed values are once again included in the organizational identity. The decision to invest time and energy in community building activity rests on the shoulders of all members and means that they must first be convinced. In addition, the flat structure of Studio K also leads to a specific kind of relationship between its members. Due to the fact that people feel no hierarchy, meeting similar people makes it easier to intensify contact and become friends. By supporting a friendship culture based on notions of equality, Studio K displays a tendency to look inward and to appear self-contained. Even other students and middle-class visitors sometimes say they feel as if they're imposing on the privacy of the organizations members with their presence. The intimacy between members of Studio K must be an even greater obstacle for people belonging to the lower class or of non-Western ethnic background; it may well prevent other people from this diverse neighborhood grabbing a cup of coffee at Studio K, as opposed to pulling up a chair at their familiar community centre.

Members asked to position Studio K in the neighborhood agreed that the organization has been of positive influence on the neighborhood. They stressed that Studio $\mathrm{K}$ has initiated a rapid change of the physical environment by attracting middle-class residents, as can be illustrated with the following quote:

'I think that we have contributed to the development of the neighborhood a lot. Before Studio K came to this place it was an impoverished neighborhood. So, after Studio $\mathrm{K}$ appeared, together with Stay Okay [a backpackers' youth hostel housed in the same building] the housing prices rose quickly, as did the business in the Studio K's surroundings. So yes, you see the neighborhood profits a lot.'

It becomes apparent that the logic of the members follows the common discourse also voiced by housing corporations and municipality, by referring to improvements of the physical appearance of public space as part of the gentrification process. The students argued that Studio K plays an important role in the neighborhood by enhancing the economic and physical capacity and by attracting younger, highly educated people. Members stated that by serving the interest of the middle classes, Studio $\mathrm{K}$ has enforced the reinvestment in the area and consequently influenced the neighborhood in a positive way. Some members even mentioned that there are a group of elderly Turkish gentlemen visiting Studio K, and that there was once a Turkish film festival. However, it becomes clear that the overall organizational activities and interests do not focus on the diverse neighborhood population. Even though Studio K does not serve many neighborhood residents, student workers still stressed there is a general acceptance of Studio K. For example:

'I don't think a possible negative feeling about Studio K is the reason why they don't come to visit it. I just think this is not the place to be for them. What Studio $\mathrm{K}$ offers is not of interest for the kind of people living in this neighborhood. They are just not interested.'

Studio $\mathrm{K}$ does not actively exclude parts of the Indische neighborhood but its members acknowledge that they have less interest in a venue such as Studio K and that most of the settled inhabitants of the neighborhood have already found their places somewhere else. Being acquainted with small cafés and community centers, they feel no need to make use of the facilities at Studio K.

New student workers were unaware of the initial concept: Studio K should be a living room for the surrounding neighborhood. They were surprised to hear an explanation of the first business plan and argued that they had never been confronted with the former ideals of Studio K. Older members that are still active in the organization had knowledge of the original plan to represent the specific interests of the neighborhood. They agreed however, that the direction of Studio $\mathrm{K}$ had clearly changed and that the current focus is on its function as a cultural centre. Members that have known Studio K before it was opened in September 2007, were familiar with the concept outlined in the first business plan and acknowledged that the communitybuilding activities had been eroded. Describing the organization's progress in the last three years, they found only a few individuals supporting the community ideal. After these individuals left the organization, activities that primarily focused on the neighborhood and community decreased, eventually vanishing. A former student worker in Studio K stressed the individual attachment of particular members to the community-related activities:

'I think it is really important to have an active
member in the organization who takes care of
the connections and networks within the
neighborhood. We had such a member. She
was a member of the board. (...) She had
many contacts, also with people from the
neighborhood, and local organizations. She
was the one who took the initiative to
participate in the Jalan Jalan festival [a
multicultural parade through the
neighborhood]. I think we miss such a person
who is willing to take these responsibilities.'

Their utterances emphasize that the success of a line of thought is detached to personal ambitions. Different student workers also stressed that the short-term nature of membership, leads to a loss of knowledge. For example
'It shouldn't be that way. In any organization it would be normal to transfer the knowledge to the successors. I think that those who were really enthusiastic to make links with the local neighborhood didn't take care of the continuation. At the same time the board often misses a clear focus.'

All members of Studio $\mathrm{K}$ are students and therefore usually leave the organization after a relatively short period of time without securing enough time to show the new oncoming members the ropes, this means knowledge about the organizations past is often diminished. Next to the reasoning based on the internal structure of Studio K, members equally agreed that the financial pressure Studio K 
found itself in during the opening resulted in a change of plans and ideals. Student workers were forced to remain vigilant with regard to financial threats, pushing them to concentrate on more lucrative projects, as reflected below:

'In the first place, I think this is because of the fact that we thought Studio K was bigger. Not bigger in the sense that we are housed in a big building, but in the sense that we overestimated our possibilities. I think that the first business plan did not take into account the fact that money is needed for the organization. One needs money first before a plan can be executed and this is why the plan has been recently modified; primarily to focus on activities that bring in much needed money. And to be honest, I think these are activities that are not rooted in the neighborhood, since the Indische neighborhood is not a rich neighborhood, it is not a place where people want to spend their money on the things we have to offer.'

The student interviewees described activities for the neighborhood community as not being of direct financial value to the organization and argued that they had been let go for that reason. Another argument they gave is that community projects were not always successful. The reasoning here is that members want to receive something in exchange for their engagement and if it's not financial compensation, they require enthusiastic neighbors joining their activities. It seems as if a number of members regarded pursuing community-related activities as a waste of time. Interviewees presumed residents already had meeting places within the neighborhood, such as neighborhood centers and small cafés which they continued to frequent. A student worker reported:

'Studio K made a lot of effort to do just that. However, we gave them, the neighborhood, the opportunity to respond to our activities, but did they really appreciate it!? If not, it's not unusual for the Studio K members to think; we did our best, but from now on we are going to focus on those groups who find us interesting enough to work with.'

In sum, the ideal of bonding with the neighborhood seems to have vanished. Additionally, most interviewees referred to the specific organizational character of Studio K, the background of members and the financial struggle attributed to the operation of Studio K in the last years. Most members were unfamiliar with any ambition to form a home for neighborhood residents and ascribed a different role to Studio K. It was to improve the neighborhood, not by bringing local people in touch with each other but by attracting a new social class with its own consumption pattern, privatizing public space and attracting attention to the square. In other words, a representation of the idea 'domestication by cappuccino' which includes similar people and excludes others who behave differently [38].

\section{THE OUTSIDERS' PERCEPTIONS}

Asked to describe the role Studio K plays within the neighborhood, outsiders mainly affirmed the assumptions made by the student workers of the organization. The Timorplein (the square on which the building is situated) was described as a prime example of how a neighborhood can be stimulated by providing new facilities attracting a different social class. Bringing new people to the Indische neighborhood, it was argued, would benefit the entire neighborhood and expand the local economy. Employees of the housing corporations describe Studio K as a new cultural and economic center for the neighborhood, which would act as a driving force to improve the overall image. Studio K seems to be relevant to the housing corporations, who promote owner-occupied housing in the neighborhood. Housing advertisements therefore always refer to Studio K as a leisure centre in the vicinity. However, entrepreneurs situated in the same building complex as Studio K, were more critical. They saw Studio K as one of the key players in relation to neighborhood revival. They did however, acknowledge that Studio K above all else, complies with the interests of the middle class, a group they subscribe to. In this respect one entrepreneur said:

'When we came here for the first time we met the type of people we were used to meeting. You won't find these people easily in this neighborhood. They go to other places. Now we have several facilities where people like to go, they consider them attractive. I remember when we first came here [Studio K], we thought: 'where do all those people come from? Could they live in this neighborhood?' On the street you see Surinamese and Turkish people. You miss them at Studio K, they don't go there.'

They made clear that Studio K pushed the neighborhood in a particular direction, adding a cultural urban sphere to it. Even though they appreciated the development of the neighborhood, they were skeptical to what extent Studio K really represents the overall population of the neighborhood. They questioned whether all neighborhood residents had evaluated the progress of the neighborhood in an equally positive way.

In contrast to the entrepreneurs, a member of the Timorplein Community - a group organizing community activities around the square - discussed whether Studio K should aim at attracting all ethnic groups in the neighborhood, or whether it would be better to serve only the 'elite':

'All right, the connections of Studio K with the neighborhood... Well, I would like to ask: 'why should Studio $\mathrm{K}$ aim to be the neighborhood's living room? Why is it wrong to say that they want to focus more on the neighborhood's elite; people like me!?' We also live in the neighborhood. We are the elite and Studio K meets our wishes. You can ask yourself: 'Is there a link with the majority of the people living in the neighborhood?' The majority prefers to stay at home and watch TV, etc. They belong to a different culture.'

This particular community member stressed that the change in the neighborhood enhanced the feeling of personal 
safety. In line with the entrepreneurs, organizers within the Timorplein Community also said that new facilities such as Studio K made the student workers feel more at home in the Indische neighborhood. One member argued that Studio $\mathrm{K}$ brought other people and new businesses into the area, resulting in a growing economic power. This member was also asked if he saw the changes as conflicting interests, after which the respondent said that there have always been struggling interests but that the development of the neighborhood has not led to increased conflict. This community member assumed that the founders of Studio K had not succeeded in becoming a neighborhood center:

'If Studio $\mathrm{K}$ decides to change its vision and mission, for example to become more professional, than you have to ensure that their vision is maintained and that the mission is sustainable. One cannot do that in a top-down fashion, and must take care that the mission becomes sustainable in cooperation with others.'

This member suggested that a combination of different target groups would be possible at Studio K, if each group received enough space to follow its specific interest. Small steps would be necessary to bring people together. In the first instance, it should stimulate curiosity and enable people to leave their comfort zone, therefore creating contact between different types of people.

\section{CONCLUSIONS}

Overall it is clear that Studio $\mathrm{K}$ did not succeed in one of their original aims to create a home for the community of neighborhood residents. In contrast, the cultural center attracted the middle classes, including students who then lived to a large extent outside the neighborhood. In fact, mechanism of inclusion and exclusion go together, but what has caused this change? The initial policy aimed at serving the neighborhood community, including its many ethnic groups as well as the lower and middle classes. However, the changing composition of students included in the management of Studio K required so much energy input that the idea of having a neighborhood community function was relegated to the background. This was strengthened by the fact that organizational facilities for the middle classes requested more attention; something needed to maintain a profitable enterprise. What happened here is that the planning of the use of the quasi public space of Studio K differs from its use in reality. Those low income neighborhood residents aimed to be included tend to be excluded by in reality. In other words, attempts to develop bonding capital among similar people became dominant over bridging different people. The idea of creating a home for many turned into creating a home for a selective group. The home created by the students is more suited to the norms and values of the middle classes and is hardly, if at all, suited to the low-income groups of non-Western origin in the neighborhood who primarily belong to the lower-class echelon.

Just as Blokland [24] argued, the local place of Studio K did not automatically induce a specific behavioral pattern. The central location of Studio $\mathrm{K}$ in the neighborhood has not created shared quasi-public space or generated activities that represent a place-relatedness of the organization. This particularistic view on belonging has shown a strong place attachment, akin to Watt's 'selective belonging' [28]. They come today and leave tomorrow, employing a mobile home strategy in which the visitors and student workers of Studio K look for a 'home' by familiarizing this quasi-public space, by partaking in the consumption of middle-class food and drink, art movies, music and by meeting look-a-likes. Studio $\mathrm{K}$ brings in mobile consumer goods to satisfy the needs of its visitors, strengthening a homely atmosphere but excluding the lower class ethnic groups to a large extent due to the lack of ethnic characteristics recognized by them as home.

This study tells us a lot about gentrification, and in particular studentification. The literature emphasizes the role of middle-class residents - mainly owner-occupiers - and student housing in the gentrification of a neighborhood, but here it is a student-led facility that is seen to contribute to the gentrification process. Here one can trace a paradox: both students working in Studio $\mathrm{K}$ and visitors with a lifestyle determined with universalist values are in principle open minded to diversity, but employ simultaneously a particularist attitude reflected by an inward-looking attitude. This shows that the clientele attracted by middle-class establishments employ a tactic of 'domestication by cappuccino' [11]. Once these middle-class islands mushroom, their influence in the neighborhood increases. Here it is more a matter of a soft re-conquering of the area by creating spaces of consumption that include the middle classes but exclude others. This study has clearly shown that organizational sociology offers both insight and explanation regarding the paradoxical mechanism of inclusion and exclusion, and the gentrification process of the neighborhood to the detriment of social mixing.

\section{CONFLICT OF INTEREST}

The authors confirm that this article content has no conflict of interest.

\section{ACKNOWLEDGEMENTS}

The authors would like to thank the students of Studio K for their hospitality and for the opportunity to do research and collect the data necessary to write this article.

\section{REFERENCES}

[1] Zielenbach S. The Art of Revitalization: Improving Conditions in Distressed Inner-City Neighborhoods. New York: Routledge 2000.

[2] Smets P, Salman T. Countering urban segregation: Theoretical and policy innovations from around the globe. Urban Stud 2008; 45(7): 1307-32.

[3] Florida R. Cities and creative class. City Comm 2003; 2(1): 3-19.

[4] Lees L. Gentrification and social mixing: Towards an inclusive urban renaissance? Urban Stud 2008; 45(12): 2449-70.

[5] Musterd S, Andersson, R. Housing mix, social mix and social: opportunities. Urban Aff Rev 2005; 40(6): 761-90.

[6] Smets P, den Uyl M. The complex role of ethnicity in urban mixing: a study of two deprived neighbourhoods in Amsterdam. Urban Stud 2008; 45(7): 1439-60.

[7] Smith N. The new urban frontier: Gentrification and the revanchist city. London, New York: Routledge 1996.

[8] Uitermark J, Duyvendak JW. Civilising the city: populism and revanchist urbanism in Rotterdam. Urban Stud 2008; 45(7): 1485503.

[9] Atkinson R. Padding the bunker: Strategies of middle-class disaffiliation and colonisation in the city. Urban Stud 2006; 43(4): 819-32.

[10] Butler T. For gentrification? Environ Plan A 2007; 39: 162-81. 
[11] Atkinson R. Introduction: Misunderstood saviour or vengeful wrecker? The many meanings and problems of gentrification. Urban Stud 2003; 40(12): 2343-50.

[12] Smith D. The politics of studentification and' (un)balanced' urban populations: lessons for gentrification and sustainable communities? Urban Stud 2008; 45(12): 2541-64.

[13] Hubbard P. Geographies of studentification and purpose-built student accommodation: leading separate lives? Environ Plan A 2009; 41: 1903-23.

[14] Smith DP, Holt L. Studentification and 'apprentice' gentrifiers within Britain's provincial towns and cities: extending the meaning of gentrification. Environ Plan A 2007; 39: 142-61.

[15] Smets P, Kreuk N. Together or Separate in the Neighbourhood? Contacts Between Natives and Turks in Amsterdam. Open Urban Stud J 2008; 1: 35-47.

[16] Boersma FK, Langen H, Smets P. Lokale betrokkenheid als uitdaging bij een culturele buurtinterventie. Rooilijn 2012; 45(1): 28-33.

[17] Chatterton P. University students and city centres - the formation of exclusive geographies. The case of Bristol. UK: Geoforum 1999; 30: pp. 117-33.

[18] White E. The Flaneur: A Stroll through the Paradoxes of Paris. New York: Bloomsburry 2001.

[19] Fischer CS. To dwell among friends: Personal networks in town and city. Chicago: University of Chicago Press 1982.

[20] Leydon KM. Social capital and the built environment: the importance of walkable neighbourhoods. Am J Public Health 2003; 93(9): 1546-551.

[21] Blackshaw T. Key concepts in community studies. Los Angeles, etc.: Sage 2010.

[22] Smets P. Community development in contemporary ethnicpluriform neighbourhoods. Commun Develop J 2011; 46(2S): 1532.

[23] Castells M. The Rise of the Network Society. Oxford: Blackwell 1997.

[24] Blokland T. Urban Bonds. Cambridge: Blackwell 2003.
[25] Weick KE. Sensemaking in Organizations. Sage: Thousand Oaks 1995.

[26] Duyvendak JW. The politics of home. Belonging and nostalgia in Western Europe and the United States. Hampshire, New York: Palgrave MacMillan 2011.

[27] Savage M, Bagnall G, Longhurst B. Globalization and Belonging. London: Sage 2005.

[28] Watt P. Living in an oasis: middle-class disaffiliation and selective belonging in an English suburb. Environ Plan A 2009; 41: 2874-92.

[29] Gioia DA. From Individual to Organizational Identity. In: Whetten DA, Goldfrey P. Eds. Identity in Organizations: Building Theory through Conversations. London, Thousand Oaks, New Delhi: Sage 1998; pp. 17-33.

[30] Albert S. The Definition and Metadefinition of Identity. In: Whetten, DA, Goldfrey P. Eds. Identity in Organizations: Building Theory Through Conversations. London, Thousand Oaks, New Delhi: Sage 1998; pp. 1-17.

[31] Alvesson M. Methodology for close up studies. Struggling with closeness and closure. High Educ 2003; 46(2): 167-93.

[32] Ybema S, Keenoy T, Oswick C, Beverungen A, Ellis N, Sabelis I. Articulating identities. Hum Relat 2009; 62(3): 299-322.

[33] Hatch MJ, Schultz M. The dynamics of organizational identity. Hum Relat 2002; 55(8): 989-1018.

[34] Ashforth BE, Harrison SH, Corley KG. Identification in Organizations: An Examination of Four Fundamental Questions. J Manag 2008; 34(3): 325-74.

[35] Humphreys M, Brown AD. Narratives of Organizational Identity and Identification: A Case Study of Hegemony and Resistance. Organ Stud 2002; 23(3): 421-47.

[36] Putnam RD, Feldstein LM with Cohen D. Better Together: Restoring the American Community. New York: Simon \& Schuster 2003.

[37] Burt RS. Brokerage \& Closure. An Introduction to Social Capital. Oxford: Oxford University Press 2005.

[38] Atkinson R. Domestication by Cappuccino or a Revenge on Urban Space? Control and Empowerment in the Management of Public Spaces, Urban Stud 2003; 40(9): 1829-43.

(C) Boersma et al.; Licensee Bentham Open.

This is an open access article licensed under the terms of the Creative Commons Attribution Non-Commercial License (http://creativecommons.org/licenses/by$\mathrm{nc} / 3.0 /$ ) which permits unrestricted, non-commercial use, distribution and reproduction in any medium, provided the work is properly cited. 